\title{
A simple and effective protocol for fast isolation of human Tenon's fibroblasts from a single trabeculectomy biopsy - a comparison of cell behaviour in different culture media
}

\author{
Agata Przekora $^{1 *}$, Tomasz Zarnowski ${ }^{2}$ and Grazyna Ginalska ${ }^{1}$
}

\author{
* Correspondence: \\ agata.przekora@umlub.pl; \\ agata.przekora@tlen.pl \\ 'Department of Biochemistry and \\ Biotechnology, Medical University of \\ Lublin, Chodzki 1 Street, 20-093 \\ Lublin, Poland \\ Full list of author information is \\ available at the end of the article
}

\begin{abstract}
Background: Human Tenon's fibroblasts (HTFs) play a crucial role in wound healing. They cause postoperative scarring of the filtering bleb and are thus responsible for trabeculectomy failure. This study aimed to find an effective and fast protocol for HTF isolation from trabeculectomy biopsies. The protocol was compared with the commonly recommended HTF isolation procedure, which uses Dulbecco's modified Eagle's medium (DMEM). We used Eagle's minimum essential medium (EMEM) enriched with fibroblast growth factor (FGF), which selectively promoted the proliferation of HTF cells. A secondary goal was to compare HTF morphology, metabolism and growth during parallel cultivation of the isolated cells in FGF-enriched EMEM and DMEM.

Results: Standard procedures for HTF isolation from tissue biopsies require a 20- to 30-day culture of the explants to obtain the first monolayer. Our protocol yielded the first monolayer after approx. 15 days. More importantly, the majority of the cells were fibroblasts with only individual epithelium-derived cells present. Using FGF-enriched EMEM allowed $1.3 \times 10^{6}$ vimentin-positive fibroblasts to be obtained from a single biopsy within approx. 25 days. Using DMEM resulted in isolation failure and required exchange to FGF-enriched medium to recover the fibroblast culture. HTFs maintained in FGF-enriched EMEM also showed faster proliferation and a different type I collagen production ability compared to HTFs cultured in DMEM. Thus, FGF-enriched EMEM is recommended for fast propagation of HTFs unless the aim of the study is to assess the effect of a tested agent on proliferation ability or type I collagen production.

Conclusions: Our fast protocol for HTF isolation allows easy setup of cell banks by researchers under laboratory conditions and could be very useful during testing of novel ophthalmologic anti-fibrotic agents in vitro. Molecular analysis of HTFs isolated from patients with known treatment histories may provide valuable information on the effects of some medications taken before glaucoma surgery on the subsequent wound-healing process and potential for trabeculectomy failure.
\end{abstract}

Keywords: Glaucoma, Ocular disorders, Cell banking, Isolation protocol, Primary culture 


\section{Background}

Glaucoma is a group of human ocular disorders characterized by progressive loss of vision resulting from optic nerve damage, often associated with increased intraocular pressure (IOP) [1, 2]. The procedures applied to decrease intraocular pressure include glaucoma medications (e.g., biomatoprost, betaxolol or levobunolol), laser therapy and trabeculectomy, which is also known as glaucoma filtering surgery [2-4]. Trabeculectomy is generally applied when medical and laser therapy have failed to sufficiently lower IOP, and in most cases, its failure is due to postoperative scarring of the filtering bleb [2-4].

Human Tenon's fibroblasts (HTFs) are the main cells responsible for initiation and mediation of wound healing and scarring after a trabeculectomy [5]. During wound healing, activated HTFs adhere to the surgical site and start excessive proliferation and accumulation of extracellular matrix (ECM) components, leading to fibrotic scar formation [4-6]. Considerable research has focused on finding anti-fibrotic agents that would inhibit HTF proliferation and ECM production to improve the success of glaucoma filtering surgery. Agents receiving special attention have included 5-fluorouracil [7, 8], mitomycin C [7], bevacizumab [3, 9-11], and ranibizumab [4].

Because HTFs play a crucial role during wound healing after a trabeculectomy, there is a huge need to establish a simple and effective method for HTF isolation that would allow for novel ophthalmologic drug testing under in vitro conditions. From a scientific point of view, it is very important to successfully culture HTFs from trabeculectomy biopsies from patients with known treatment histories.

Before glaucoma filtering surgery, many patients take medications to decrease IOP. Moreover, anti-fibrotic agents are often administrated intraoperatively to inhibit HTF proliferation [3]. However, it is commonly observed that despite the administration of anti-fibrotic agents, postoperative scarring of the filtering bleb occurs very rapidly. This phenomenon is often associated with long-term therapy with anti-glaucoma medications [2].

Tissue biopsies taken during a trabeculectomy and further molecular analysis of HTF culture in vitro combined with the patient treatment history may provide valuable information regarding the effects of medications taken before the surgery on wound healing. As trabeculectomy biopsies are usually very small $(1-2 \mathrm{~mm}$ in length), HTF isolation is a challenging task. It is very difficult to obtain a sufficient number of primary HTF cells from a single trabeculectomy specimen for further in vitro experiments.

The primary aim of this study was to establish a new, simple and effective protocol for HTF isolation from a single $2-3 \mathrm{~mm} \times 1 \mathrm{~mm}$ trabeculectomy biopsy and to compare it with the standard procedure using basal DMEM, which is widely described in the available literature as a recommended medium for HTF isolation (Fig. 1). Unlike most researchers, we propose a simple "outgrowth" method without collagenase digestion, using basal EMEM supplemented with key factors for fibroblast proliferation: fibroblast growth factor, insulin and vitamin $C$. It is worth emphasizing that we are the first to present a fast protocol for HTF isolation from a single trabeculectomy biopsy of approx. 2-3 $\mathrm{mm} \times 1 \mathrm{~mm}$. The secondary goal was to compare cell morphology, size, viability, proliferation, and ability to produce type I collagen during parallel cultivation of isolated HTFs in FGF-enriched EMEM and basal DMEM. 


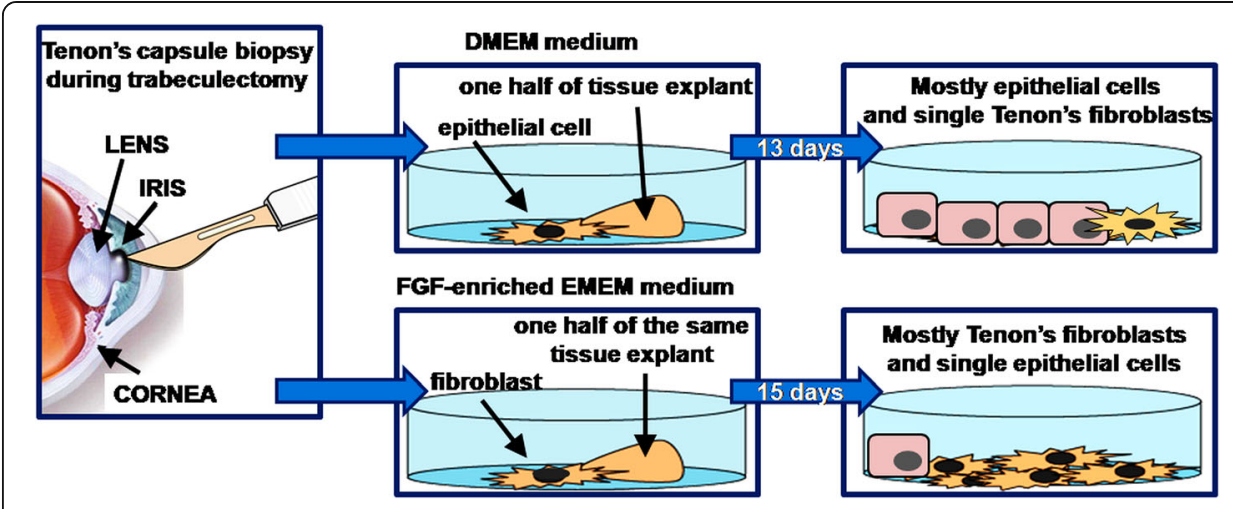

Fig. 1 A graphic representation of the main concept of the research

\section{Methods}

\section{Collection of trabeculectomy specimens}

The Tenon's biopsies were collected from 3 male patients $(n=3)$ aged $65-75$ years who had newly diagnosed advanced open-angle glaucoma, had no previous medical therapy for the condition, and were undergoing trabeculectomy. Table 1 shows patient data. The tissue specimens were taken during the first step of the glaucoma filtering surgery. After conjunctiva separation, performed with the microscissors on the upper part of the eye bulb, a small piece of the Tenon's capsule was harvested from the scleral area near the corneal limbus at 12 o'clock. The further steps of the surgery were typical for trabeculectomy $[3,11,12]$ and did not influence specimen collection.

The isolated biopsy tissue, approx. $2-3 \mathrm{~mm} \times 1 \mathrm{~mm}$ in size, was placed onto a moist tampon and transferred to a sterile $15 \mathrm{ml}$ centrifuge tube containing $5 \mathrm{ml}$ of $300 \mathrm{U} / \mathrm{ml}$ penicilin, $300 \mu \mathrm{g} / \mathrm{ml}$ streptomycin, and $0.75 \mu \mathrm{g} / \mathrm{ml}$ amphotericin B solution (SigmaAldrich Chemicals) prepared in phosphate buffered saline (PBS; Sigma-Aldrich Chemicals). Collected specimens were immediately transported to the laboratory for the isolation.

\section{Isolation and culture of HTFs}

The tissue biopsies were washed twice with PBS and cut into 2 pieces using a sterile scalpel. These were placed in separate wells of a 12-well plate using light pressure and left to air dry for up to $1 \mathrm{~min}$ to attach to the well bottom.

Parallel isolations for each tissue biopsy were set up using 2 different culture media:

1) $800 \mu \mathrm{l}$ of basal EMEM (ATCC - LGC Standards) supplemented with $5 \%$ foetal bovine serum (FBS, EU Professional grade, Pan-Biotech), $5 \mu \mathrm{g} / \mathrm{ml} \mathrm{recombinant}$ human (rh) insulin, $5 \mathrm{ng} / \mathrm{ml} \mathrm{rh}$ basic fibroblast growth factor (rh FGF b), $50 \mu \mathrm{g} / \mathrm{ml}$

Table 1 Data about the patients from whom the specimens were collected

\begin{tabular}{lllll}
\hline Patient & Sex & Age & Systemic diseases & Previous anti-glaucoma therapy \\
\hline 1 & male & 65 & hypertension & none \\
2 & male & 70 & none & none \\
3 & male & 75 & hypertension & none \\
\hline
\end{tabular}


ascorbic acid (components of Fibroblast Growth Kit, ATCC - LGC Standards),

$7 \mathrm{mM}$ L-glutamine (Sigma-Aldrich Chemicals), $100 \mathrm{U} / \mathrm{ml}$ penicilin, $100 \mu \mathrm{g} / \mathrm{ml}$

streptomycin, and $0.25 \mu \mathrm{g} / \mathrm{ml}$ amphotericin B

2) $800 \mu \mathrm{l}$ of basal DMEM (Sigma-Aldrich Chemicals) supplemented with 10\% FBS, $100 \mathrm{U} / \mathrm{ml}$ penicilin, $100 \mu \mathrm{g} / \mathrm{ml}$ streptomycin, and $0.25 \mu \mathrm{g} / \mathrm{ml}$ amphotericin B.

The resulting supplemented EMEM is referred to as 5\% FGF-EMEM and complete DMEM is referred to as $10 \%$ DMEM throughout this article.

The explants were maintained at $37{ }^{\circ} \mathrm{C}$ in a humidified atmosphere of $5 \% \mathrm{CO}_{2}$ and $95 \%$ air and the culture medium was renewed every 3 days. When the cells formed a monolayer, trypsinization $\left(1-3 \mathrm{~min}\right.$ at $\left.37{ }^{\circ} \mathrm{C}\right)$ using $1 \mathrm{ml}$ of $0.12 \%$ trypsin-EDTA solution without phenol red (Sigma-Aldrich Chemicals) was performed to detach the cells. The detached cells were then resuspended in $10 \mathrm{ml}$ of fresh culture medium and transferred to $15 \mathrm{ml}$ centrifuge tubes. Cells that were still attached to the culture dish surface after trypsinization were detached using a cell scraper and transferred to the same $15 \mathrm{ml}$ centrifuge tubes.

The cells were centrifuged at $125 \times \mathrm{g}$ for $5 \mathrm{~min}$, the pellet was resuspended in $5 \mathrm{ml}$ of fresh culture medium, and the cells were seeded (approx. 2.4-4 $\times 10^{3}$ cells per $\mathrm{cm}^{2}$ of the growth area dependent on the sample) in a $25 \mathrm{~cm}^{2} \mathrm{~T}$-flask and cultured at $37{ }^{\circ} \mathrm{C}$ in a humidified atmosphere of $5 \% \mathrm{CO}_{2}$ and $95 \%$ air (passage 1 ).

When the cells reached $90 \%$ confluence, the second passage by trypsinization using $2 \mathrm{ml}$ of $0.12 \%$ trypsin-EDTA solution (approx. $1-2 \mathrm{~min}$ at $37{ }^{\circ} \mathrm{C}$ were sufficient) was performed using two $25 \mathrm{~cm}^{2}$ T-flasks (seeding density of $1.2 \times 10^{4}$ cells per $\mathrm{cm}^{2}$ of the growth area). The cells were also seeded in wells $\left(1 \times 10^{4}\right.$ cells per well $)$ of a 96-well plate to stain vimentin filaments.

After passage 2, fibroblasts reached confluence within $48 \mathrm{~h}$. During the isolation procedure, the cell morphology was constantly monitored under an optical microscope (Olympus CKX31 or Nikon Eclipse TS100) and the obtained images were analyzed using ImageJ software.

\section{Recommended freezing medium and cryopreservation protocol}

Two $25 \mathrm{~cm}^{2}$ T-flasks with confluent HTF culture from a single tissue biopsy were obtained $48 \mathrm{~h}$ after the second passage. The cells were then trypsinized, washed with fresh medium via centrifugation at $125 \times \mathrm{g}$ for $5 \mathrm{~min}$ and collected for cryopreservation using a freezing medium composed of 72\% DMEM, 20\% FBS and 8\% DMSO (SigmaAldrich Chemicals). A Nalgene Cryo $1{ }^{\circ} \mathrm{C}$ Freezing Container was used to achieve a $-1{ }^{\circ} \mathrm{C}$ per min rate of cooling. The vials $(1.8 \mathrm{ml})$ in the container were placed in a $-70^{\circ}$ $\mathrm{C}$ freezer for $12 \mathrm{~h}$, then placed in liquid nitrogen vapour for $24 \mathrm{~h}$ and then in liquid nitrogen for long-term storage.

\section{Vimentin and F-actin filaments staining}

Second passage HTF cells were seeded in the wells of a flat-bottom 96-well plate in $100 \mu \mathrm{l}$ of complete culture medium at a concentration of $1 \times 10^{5}$ cells $/ \mathrm{ml}\left(1 \times 10^{4}\right.$ cells per well) and cultured for $48 \mathrm{~h}$ at $37{ }^{\circ} \mathrm{C}$ in an atmosphere of $5 \% \mathrm{CO}_{2}$. To visualize the cytoskeletal filaments (vimentin and actin), cells were fixed according to a previously 
described procedure [13]. Briefly, cells were washed with PBS buffer, fixed with 3.7\% formaldehyde (Avantor Performance Materials) for $10 \mathrm{~min}$, permeabilized with $0.2 \%$ TritonX-100 (Sigma-Aldrich Chemicals) for $15 \mathrm{~min}$ and incubated with a blocking solution of $1 \%$ bovine serum albumin (BSA; Sigma-Aldrich Chemicals) for $30 \mathrm{~min}$. Vimentin, a specific marker of mesenchymal cells that are highly expressed in fibroblasts, was visualized using the direct immunofluorescence technique. Cells were incubated with AlexaFluor488-conjugated mouse anti-vimentin (V9) monoclonal antibodies (Abcam) at a concentration of $1 \mu \mathrm{g} / \mathrm{ml}$ overnight at $4{ }^{\circ} \mathrm{C}$. Afterwards, cells were washed with PBS buffer and simultaneously stained for $30 \mathrm{~min}$ at room temperature with 2 units of phallotoxin-AlexaFluor635 conjugate (Invitrogen) for F-actin filament labelling and $0.5 \mu \mathrm{g} / \mathrm{ml}$ DAPI (Sigma-Aldrich Chemicals) for nucleus counterstaining. To reduce nonspecific background staining, the working solution of fluorescent dyes was prepared in 1\% BSA. Stained cells were observed under a fluorescence laser scanning microscope using the two-dimensional scan technique (Olympus Fluoview IV81 equipped with FV1000 laser scanner). Tenon's fibroblasts revealed vimentin-positive (green) and actin-positive (red) fluorescence of cytoskeletal filaments, whereas epithelium-derived cells were vimentin-negative and showed only red fluorescence of actin filaments.

\section{Viability of the cells after thawing}

After long-term storage in liquid nitrogen, the cells were rapidly thawed by placing the vials in a $37^{\circ} \mathrm{C}$ water bath. Then, the viability of the cells was determined using a Countess automated cell counter (Invitrogen), which evaluates cell number and viability based on trypan blue staining.

\section{Parallel cultivation of HTFs in 5\% FGF-EMEM and 10\% DMEM}

Upon thawing, the cells were washed with fresh medium via centrifugation at $125 \times \mathrm{g}$ for $5 \mathrm{~min}$ and seeded (approx. $1.2 \times 10^{4}$ cells per $\mathrm{cm}^{2}$ of the growth area) in two $25 \mathrm{~cm}^{2}$ T-flasks. Since 10\% DMEM is widely described in the available literature as a recommended medium for maintenance and propagation of isolated HTFs, the thawed cells were cultured in parallel in two different media: 5\% FGF-EMEM and 10\% DMEM. When the cells reached $90 \%$ confluence, they were detached by trypsinization and seeded in 96-well plates to evaluate the effect of applied culture medium on HTF morphology and size, viability, proliferation, and type I collagen production.

\section{Viability comparison}

HTF cells were seeded in the wells of a flat-bottom 96-well plate in $100 \mu \mathrm{l}$ of the complete culture medium at a concentration of $1.5 \times 10^{5}$ cells $/ \mathrm{ml}\left(1.5 \times 10^{4}\right.$ cells per well) and cultured for $24 \mathrm{~h}$ at $37{ }^{\circ} \mathrm{C}$ in 5\% FGF-EMEM and 10\% DMEM. Cell viability was determined by double fluorescent staining of the nuclei of dead cells with propidium iodide (red fluorescence) and the cytoplasm of viable cells with calcein-AM (green fluorescence). The dyes were the components of the Live/Dead Double Staining Kit (Sigma-Aldrich Chemicals). The staining procedure was performed according to the manufacturer's protocol. Stained HTFs were observed under a fluorescence laser scanning microscope using the two-dimensional scan technique. 
The viability of HTFs was also assessed quantitatively based on their metabolic activity using the MTT test (Sigma-Aldrich Chemicals). After $24 \mathrm{~h}$ incubation, $25 \mu \mathrm{l}$ of MTT solution (5 $\mathrm{mg} / \mathrm{ml}$ in PBS) was added to each well and the cells were returned to the $\mathrm{CO}_{2}$ incubator for $3 \mathrm{~h}$. Then, formed formazan crystals were dissolved using $100 \mu \mathrm{l}$ of $10 \%$ SDS solution (Sigma-Aldrich Chemicals) prepared in $0.01 \mathrm{M} \mathrm{HCl}$ (Avantor Performance Materials). After $12 \mathrm{~h}$ incubation, the absorbance was measured at 570 nm using a BioTek Synergy H4 Hybrid Microplate Reader.

\section{Cell morphology and size}

HTF cells were seeded in wells of a flat-bottom 96-well plate in $100 \mu \mathrm{l}$ of the complete culture medium at a very low concentration of $1.5 \times 10^{4}$ cells $/ \mathrm{ml}\left(1.5 \times 10^{3}\right.$ cells per well $)$ and cultured for $24 \mathrm{~h}$ at $37^{\circ} \mathrm{C}$ in 5\% FGF-EMEM and 10\% DMEM. Then, cells were fixed and stained using phallotoxin-AlexaFluor635 conjugate and DAPI dye as described in the Vimentin and F-actin filaments staining section. The morphology of the stained cells was observed under a fluorescence laser scanning microscope. For each sample, images were taken from 4 randomly selected fields of view and a spreading area of at least 60 individual cells was measured using ImageJ software.

\section{Proliferation ability}

HTF cells were seeded in wells of a flat-bottom 96-well plate in $100 \mu$ l of the complete culture medium at a very low concentration of $1.5 \times 10^{4}$ cells $/ \mathrm{ml}\left(1.5 \times 10^{3}\right.$ cells per well) and cultured for 7 days at $37{ }^{\circ} \mathrm{C}$ in 5\% FGF-EMEM and 10\% DMEM. Every 2-3 days, the culture media were renewed. On the $1^{\text {st }}, 3^{\text {rd }}$ and $7^{\text {th }}$ days of the experiment, cell number was determined based on the WST- 8 proliferation test (Sigma-Aldrich Chemicals) and the calibration curve was prepared for known concentrations of cells. The test was performed according to the manufacturer's protocol. The growth rate and doubling time of the cells were calculated using Doubling Time Computing software.

\section{Type I collagen production}

HTF cells were seeded in wells of black, clear and flat-bottom 96-well plates in $100 \mu \mathrm{l}$ of the complete culture medium at a low concentration of $3 \times 10^{4}$ cells $/ \mathrm{ml}\left(3 \times 10^{3}\right.$ cells per well) and cultured for 4 days at $37{ }^{\circ} \mathrm{C}$ in 5\% FGF-EMEM and 10\% DMEM. Then, cell number was determined based on the WST-8 test and calibration curve as described in the Proliferation ability section. Since WST-8 is nontoxic to the cells, the same plates were used for type I collagen (Col I) synthesis evaluation via the indirect immunofluorescence technique. The cells were fixed as described in the Vimentin and F-actin filaments staining section and incubated with primary goat anti-type I collagen (Col1a1/Col1a2) polyclonal antibodies (Abnova) at a concentration of $20 \mu \mathrm{g} / \mathrm{ml}$ (prepared in $1 \%$ BSA) overnight at $4{ }^{\circ} \mathrm{C}$. Afterwards, the cells were washed with PBS and incubated with $2 \mu \mathrm{g} / \mathrm{ml}$ of the secondary AlexaFluor647-conjugated donkey anti-goat IgG polyclonal antibodies (Abcam) for $1 \mathrm{~h}$ at room temperature. For quantitative evaluation, the fluorescence intensity was read using a BioTek Synergy H4 Hybrid Microplate Reader with the excitation wavelength at $628 \mathrm{~nm}$ and emission wavelength at $670 \mathrm{~nm}$ (area-scan readings were recorded). The fluorescence intensity was normalized per $10^{3}$ cells. To visualize Col I in HTF cultures, the nuclei of the cells were 
additionally stained using $0.5 \mu \mathrm{g} / \mathrm{ml}$ DAPI. Col I production by HTFs was observed under a fluorescence laser scanning microscope using the three-dimensional scan technique.

\section{Results}

Isolation of HTF culture

Three parallel HTF isolations were performed using tissue specimens obtained from 3 different patients $(n=3)$ and each time the scenario was the same. Application of $5 \%$ FGF-EMEM allowed for achievement of the first monolayer in a single well of a 12well plate after an average time of 15 days of culture (Table 2), which is very short time taking into account the single $2-3 \mathrm{~mm} \times 1 \mathrm{~mm}$ biopsy used for the isolation.

More importantly, healthy outgrowth of spindle-shaped fibroblasts with individual (if any) epithelial-like cells was observed (Fig. 2a). Initial fibroblast outgrowth occurred on the approx. $4^{\text {th }}$ day. This concurs with De Falco et al. [14] and Gross [15], who demonstrated that initial, crucial adhesion of the cells from explants is observed between 4 and 8 days.

Similarly, a relatively short time (an average of 13 days) was required to reach first monolayer when 10\% DMEM was used (Table 3). However, in the case of 10\% DMEM, the monolayer of cells was predominantly composed of epithelium-derived cells and only single fibroblasts (Fig. 2b). For comparison, De Falco et al. used 10\% DMEM and relatively large specimens (approx. $12 \mathrm{~mm} \times 2.5 \mathrm{~mm}$ biopsies obtained after vitreoretinal surgery) to set up HTF culture and demonstrated that long-term incubation, approx. 20-30 days, was required to form the first monolayer [14].

When cells formed the first monolayer, passage 1 was performed regardless of the applied culture medium. After passage 1, cells reached $90 \%$ confluence $\left(2.2 \times 10^{4}\right.$ cells \pm $0.2 \times 10^{4}$ cells per $\mathrm{cm}^{2}$ ) in a $25 \mathrm{~cm}^{2}$ T-flask within an average time of 7 days when $5 \%$ FGF-EMEM was used (Tables 2 and 4). Moreover, there were only spindle-shaped fibroblasts (Fig. 2c). On the approx. $23^{\text {rd }}$ day of the isolation, passage 2 was carried out using two $25 \mathrm{~cm}^{2}$ T-flasks and HTFs formed a monolayer within $48 \mathrm{~h}$ (Table 2). Immunofluorescent staining of vimentin, a specific marker of fibroblasts, revealed that near $100 \%$ of the cells after passage 2 were vimentin-positive (Fig. 3a and c).

Unlike 5\% FGF-EMEM, in the case of isolation conducted using 10\% DMEM, 7 days after passage 1 there was low density culture of mainly epithelial-like cells and single

Table 2 HTF isolation using 5\% FGF-EMEM

\begin{tabular}{|c|c|c|c|c|}
\hline $\begin{array}{l}\text { Description of each isolation } \\
\text { step }\end{array}$ & $\begin{array}{l}\text { Passage } \\
\text { number }\end{array}$ & $\begin{array}{l}\text { Culture dish } \\
\text { used }\end{array}$ & $\begin{array}{l}\text { Time needed to } \\
\text { reach monolayer }\end{array}$ & $\begin{array}{l}\text { Features of obtained } \\
\text { monolayer }\end{array}$ \\
\hline $\begin{array}{l}\text { Biopsy cutting and setting up } \\
\text { of the isolation }\end{array}$ & 0 & $\begin{array}{l}\text { Well of } 12- \\
\text { well plate }\end{array}$ & $15.3 \pm 2.1$ days & $\begin{array}{l}\text { Mostly HTFs, possible single } \\
\text { epithelial cells }\end{array}$ \\
\hline $\begin{array}{l}\text { Cell detachment using trypsin } \\
\text { and cell scraper }\end{array}$ & 1 & $\begin{array}{l}\text { One } \\
25 \mathrm{~cm}^{2} \mathrm{~T} \text { - } \\
\text { flask }\end{array}$ & $7.3 \pm 0.6$ days & Mostly HTFs \\
\hline Cell detachment using trypsin & 2 & $\begin{array}{l}\text { Two } \\
25 \mathrm{~cm}^{2} \mathrm{~T}- \\
\text { flasks }\end{array}$ & 2 days & $\begin{array}{l}99-100 \% \text { of vimentin- } \\
\text { positive HTFs }\end{array}$ \\
\hline $\begin{array}{l}\text { Trypsinization and } \\
\text { cryopreservation of HTFs }\end{array}$ & - & - & - & - \\
\hline
\end{tabular}




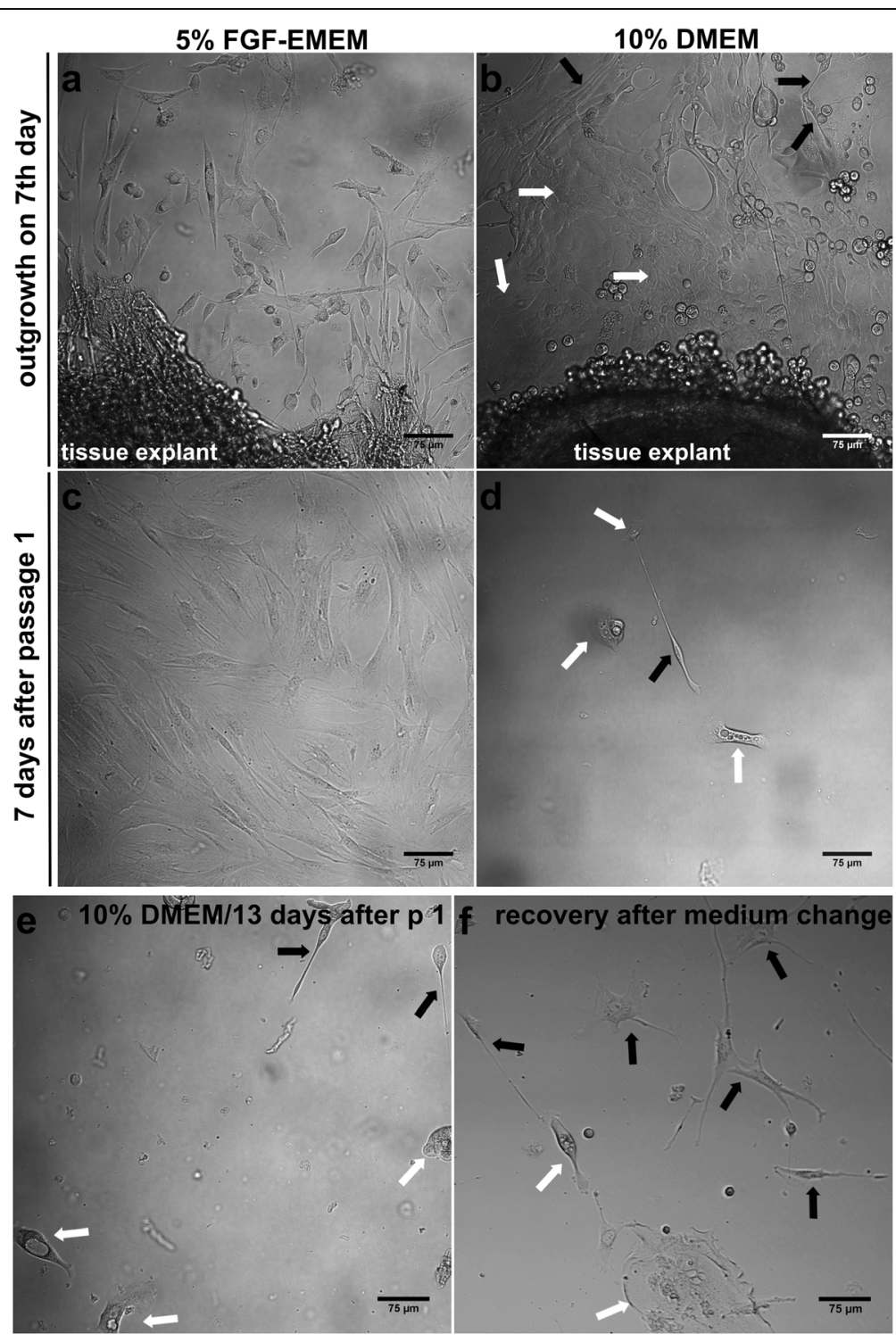

Fig. 2 Nomarski contrast images of cells during parallel isolations from the same single trabeculectomy biopsy using 5\% FGF-EMEM and 10\% DMEM. a - Healthy outgrowth of only fibroblasts from the explant when $5 \%$ FGF-EMEM was used. $\mathbf{b}$ - Healthy outgrowth of a co-culture of predominant epithelium-derived cells (white arrows) and single HTFs (black arrows) from the explant when 10\% DMEM was used. c - Monolayer of HTFs 7 days after passage 1 when 5\% FGF-EMEM was used. $\mathbf{d}$ - Few epithelium-derived cells (white arrows) and single fibroblast (black arrow) 7 days after passage 1 when 10\% DMEM was used. e -Few epithelium-derived cells (white arrows) and fibroblasts (black arrows) 13 days after passage 1 when 10\% DMEM was used. f - Initial recovery of HTF culture 4 days after medium change to 5\% FGF-EMEM (black arrows indicate fibroblasts, white arrows indicate epithelium-derived cells); scale bar $=75 \mu \mathrm{m}$, magnification 200x

fibroblasts $\left(3.9 \times 10^{2}\right.$ cells $\pm 1.3 \times 10^{2}$ cells per $\mathrm{cm}^{2}$; Fig. $\left.2 \mathrm{~d}\right)$. All 3 tissue specimens $(n=3)$ were maintained in $10 \%$ DMEM for 13 days after passage 1 (Table 3 ). On the $26^{\text {th }}$ day of the isolation (13 days after passage 1 ) there were still a few clusters of epithelium-derived cells and only single spindle-shaped fibroblasts (Fig. 2e), so it was decided to change the medium from 10\% DMEM to 5\% FGF-EMEM at this point. In the case of sample number 2, medium exchange did not result in HTF recovery and the isolation failed (Table 4). In the other two samples, medium replacement resulted in rapid HTF division rates. 
Table 3 HTF isolation using 10\% DMEM

\begin{tabular}{|c|c|c|c|c|}
\hline $\begin{array}{l}\text { Description of each isolation } \\
\text { step }\end{array}$ & $\begin{array}{l}\text { Passage } \\
\text { number }\end{array}$ & $\begin{array}{l}\text { Culture dish } \\
\text { used }\end{array}$ & $\begin{array}{l}\text { Time needed to } \\
\text { reach monolayer }\end{array}$ & $\begin{array}{l}\text { Features of obtained } \\
\text { monolayer }\end{array}$ \\
\hline $\begin{array}{l}\text { Biopsy cutting and setting up } \\
\text { of the isolation }\end{array}$ & 0 & $\begin{array}{l}\text { Well of } 12- \\
\text { well plate }\end{array}$ & $13.3 \pm 3.1$ days & $\begin{array}{l}\text { Co-culture of mostly epithelia } \\
\text { cells and single HTFs }\end{array}$ \\
\hline $\begin{array}{l}\text { Cell detachment using trypsin } \\
\text { and cell scraper }\end{array}$ & 1 & $\begin{array}{l}\text { One } \\
25 \mathrm{~cm}^{2} \mathrm{~T} \text { - } \\
\text { flask }\end{array}$ & 13 days- failure & $\begin{array}{l}\text { Few clusters of epithelial cells } \\
\text { and single HTFs }\end{array}$ \\
\hline $\begin{array}{l}\text { Medium change from DMEM } \\
\text { to FGF-enriched EMEM }\end{array}$ & - & $\begin{array}{l}\text { One } \\
25 \mathrm{~cm}^{2} \mathrm{~T} \text { - } \\
\text { flask }\end{array}$ & $15.5 \pm 2.1$ days & $\begin{array}{l}\text { Mostly HTFs and single } \\
\text { epithelial cells }\end{array}$ \\
\hline Cell detachment using trypsin & 2 & $\begin{array}{l}\text { Two } \\
25 \mathrm{~cm}^{2} \mathrm{~T}- \\
\text { flasks }\end{array}$ & 2 days & $\begin{array}{l}99-100 \% \text { of vimentin-positive } \\
\text { HTFs }\end{array}$ \\
\hline $\begin{array}{l}\text { Trypsinization and } \\
\text { cryopreservation of HTFs }\end{array}$ & - & - & - & - \\
\hline
\end{tabular}

However, the cells required at least 4-6 days to start recovery (Fig. 2f). As a consequence, fibroblasts surpassed epithelium-derived cells in growing and in an average of 15 days after medium exchange, the HTFs achieved 90\% confluence (Table 3). On the approx. $43^{\text {rd }}$ day of the isolation, passage 2 was carried using two $25 \mathrm{~cm}^{2}$ T-flasks and the HTFs formed a monolayer within $48 \mathrm{~h}$ (Table 3). Fluorescence laser scanning microscope observation performed after passage 2 showed that over $99 \%$ of the cells were actin-positive and vimentin-positive, indicating that they were in fact fibroblast cells (Fig. $3 b$ and d).

The efficiency of the isolation was high: the protocol enabled the isolation of $1.3 \times 10^{6}$ vimentin-positive fibroblasts (near $100 \%$ of the cell suspension) from a single 2-3 $\mathrm{mm} \times 1 \mathrm{~mm}$ trabeculectomy biopsy. The procedure performed for the single biopsy resulted in cryopreservation of two $1.8 \mathrm{ml}$ vials and each vial contained $6.6 \times 10^{5} \pm 0.8 \times 10^{5}$ cells. More importantly, the new protocol allowed the maintenance of high viability of HTFs through long-term storage (8-12 months) in

Table 4 Key times during 3 parallel isolations using 5\% FGF-EMEM and 10\% DMEM with medium change to 5\% FGF-EMEM

\begin{tabular}{|c|c|c|c|}
\hline $\begin{array}{l}\text { Type of } \\
\text { sample }\end{array}$ & $\begin{array}{l}\text { Time from biopsy to } \\
\text { passage } 1 \text { (days) }\end{array}$ & $\begin{array}{l}\text { Time from passage } 1 \text { to } \\
\text { passage } 2 \text { (days) }\end{array}$ & $\begin{array}{l}\text { Time of complete procedure, from } \\
\text { biopsy to cryopreservation (days) }\end{array}$ \\
\hline $\begin{array}{l}\text { Sample } 1 / 5 \% \\
\text { FGF-EMEM }\end{array}$ & 17 & 7 & 26 \\
\hline $\begin{array}{l}\text { Sample 2/5\% } \\
\text { FGF-EMEM }\end{array}$ & 13 & 8 & 23 \\
\hline $\begin{array}{l}\text { Sample 3/5\% } \\
\text { FGF-EMEM }\end{array}$ & 16 & 7 & 25 \\
\hline Mean \pm SD & $15.3 \pm 2.1$ & $7.3 \pm 0.6$ & $24.7 \pm 1.5$ \\
\hline $\begin{array}{l}\text { Sample } 1 / 10 \% \\
\text { DMEM/5\% } \\
\text { FGF-EMEM }\end{array}$ & 14 & 30 & 46 \\
\hline $\begin{array}{l}\text { Sample } 2 / 10 \% \\
\text { DMEM/5\% } \\
\text { FGF-EMEM }\end{array}$ & 10 & failure & failure \\
\hline $\begin{array}{l}\text { Sample } 3 / 10 \% \\
\text { DMEM/5\% } \\
\text { FGF-EMEM }\end{array}$ & 16 & 27 & 45 \\
\hline Mean \pm SD & $13.3 \pm 3.1$ & $28.5 \pm 2.1$ & $45.5 \pm 0.7$ \\
\hline
\end{tabular}

Bold data are the mean values 


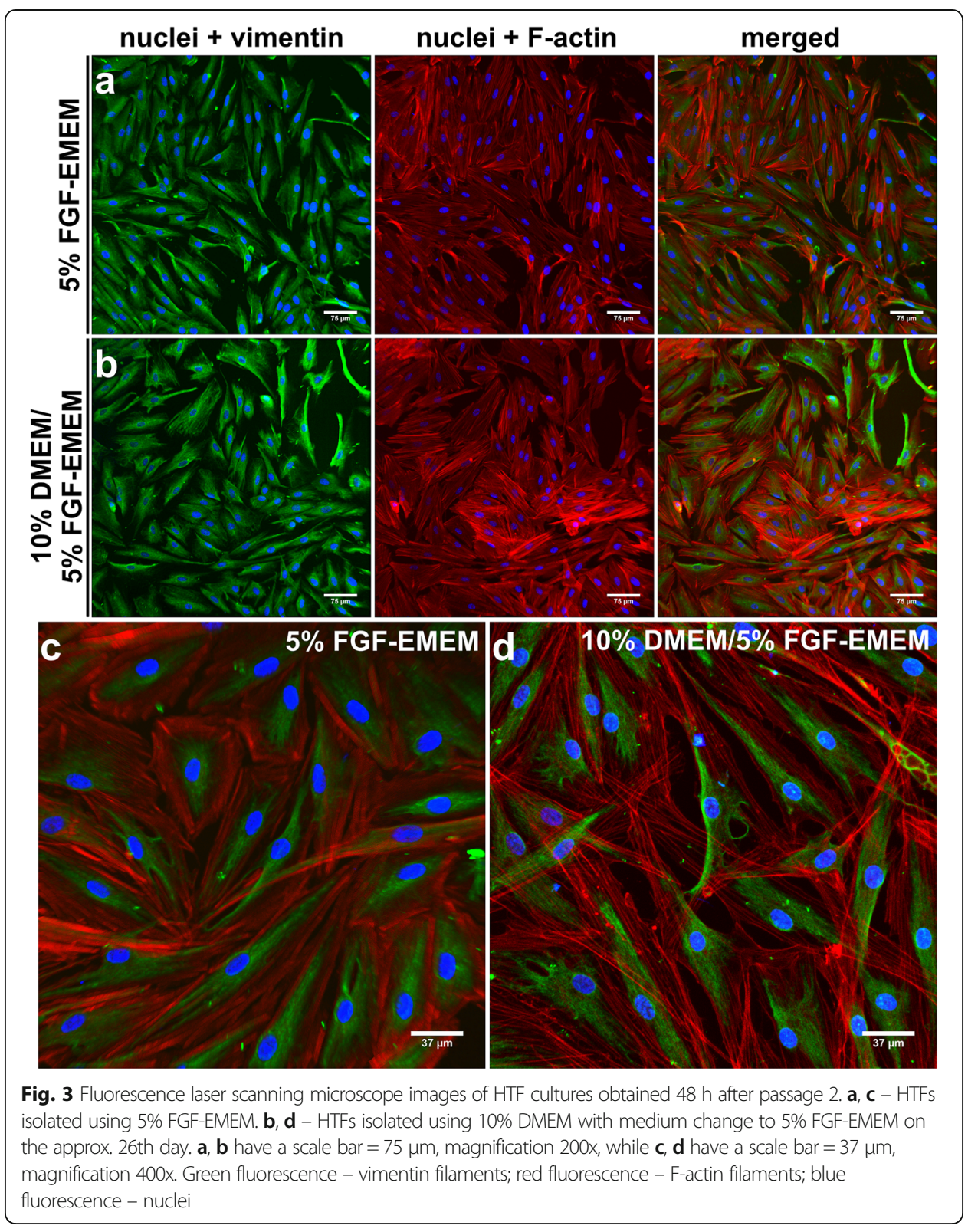

liquid nitrogen (Table 5). After thawing, the cells revealed an average viability of $94 \% \pm 2.6 \%$ (see Additional file 1).

\section{Parallel cultivation of HTFs in 5\% FGF-EMEM and 10\% DMEM}

Live/dead fluorescent staining followed by microscopic observation demonstrated that regardless of culture medium applied for HTF maintenance, cell viability was high (Fig. 4a and b). Microscopic images showed a high-density culture of viable HTF cells with green fluorescence. Red fluorescence indicating the nuclei of dead cells was not detected. The MTT viability test confirmed that the type of culture medium had no effect on cell viability and showed comparable metabolic activity of HTFs regardless of the medium used for cell cultivation (Fig. 4c). 
Table $\mathbf{5}$ Viability of HTFs after long-term storage in liquid nitrogen

\begin{tabular}{lll}
\hline Sample no. & Time of storage (months) & Viability after thawing (\%) \\
\hline Sample 1 & 12 & 93 \\
Sample 2 & 8 & 92 \\
Sample 3 & 11 & 97 \\
\hline
\end{tabular}

Interestingly, HTF morphology, size, proliferation ability and Col I production ability were highly dependent on the applied culture medium. HTFs maintained in 5\% FGFEMEM were relatively small and had mostly spindle- or stellate-shaped morphology (Fig. 5a), whereas HTFs cultured in 10\% DMEM were mostly large stellate-shaped cells (Fig. 5b). Moreover, the average size (spreading area) of the cells maintained in 5\% FGF-EMEM was almost 4-fold lower $\left(3353 \mu \mathrm{m}^{2} \pm 1680 \mu \mathrm{m}^{2}\right)$ than the spreading area of HTFs cultured in 10\% DMEM (12019 $\mu^{2} \pm 6785 \mu \mathrm{m}^{2}$; Fig. 5c).

The type of culture medium used for cultivation of HTFs had also great impact on the cell proliferation ability, and thus on their growth rate and doubling time. Fibroblasts cultured in 5\% FGF-EMEM revealed significantly faster proliferation and growth rates, resulting in meaningfully shorter doubling time $(32.33 \mathrm{~h})$ compared to the cells maintained in 10\% DMEM (45.92 h; Fig. 6).

Considerable differences in Col I synthesis were also observed between the cells cultured in 5\% FGF-EMEM and 10\% DMEM. In the case of HTFs cultured in 5\% FGF-EMEM, microscopic observation showed both intracellular formation of Col I protein and the accumulation of large and elongated collagen fibrils in the extracellular space (Fig. 7a). HTFs maintained in 10\% DMEM revealed only intracellular accumulation of considerable amounts of Col I molecules (Fig. 7b). Surprisingly, despite the formation of an extensive network of Col I fibrils (a major component of ECM) by HTFs cultured in 5\% FGF-EMEM, the analysis of the intensity of Col I fluorescence normalized per $10^{3}$ cells revealed that HTFs maintained in $10 \%$ DMEM produced slightly higher amounts of Col I than cells cultivated in 5\% FGFEMEM (Fig. 7c). Although only a slight difference in fluorescence intensity between the cells maintained in the different media was recorded, the result is considered statistically significant $(p=0007)$.

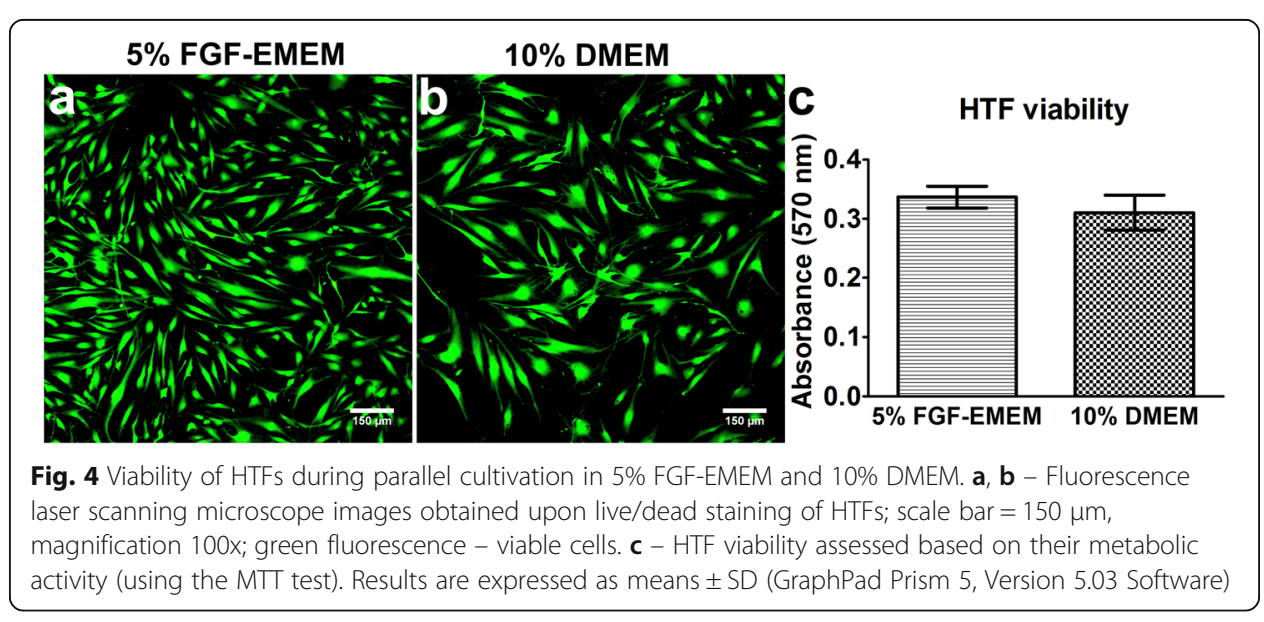




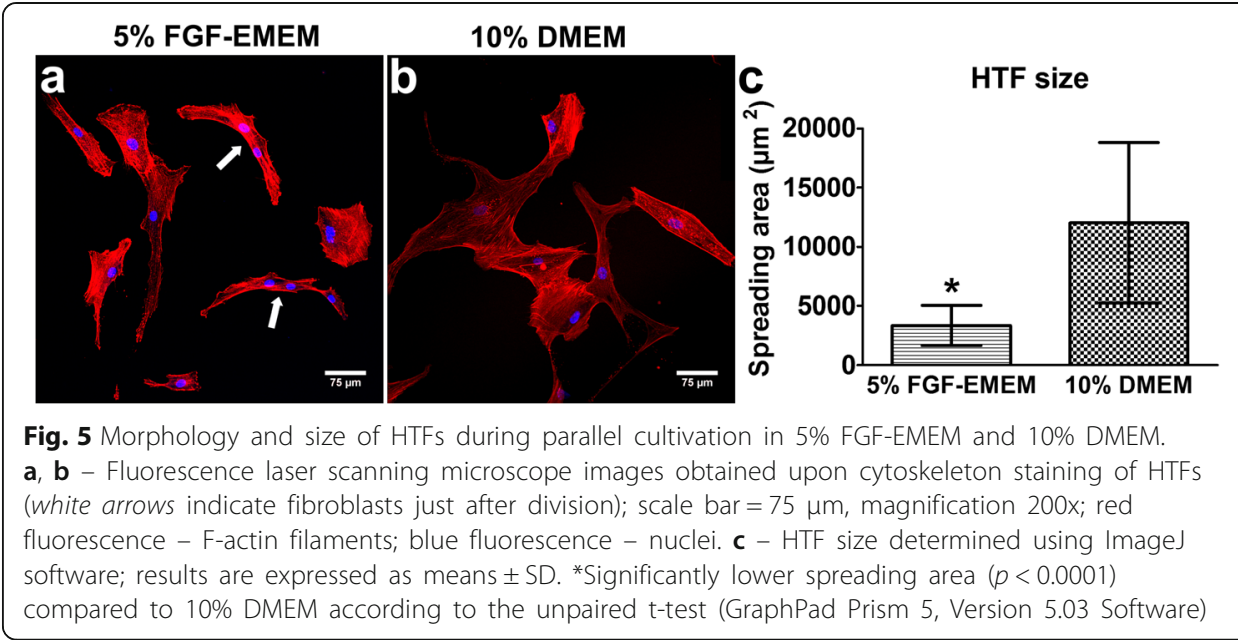

\section{Discussion}

In this study, two different culture media were used for HTF isolation: basal EMEM supplemented with key factors for fibroblast proliferation; and the commonly recommended medium for this purpose, basal DMEM. It was demonstrated that effective HTF isolation was possible only when 5\% FGF-EMEM was used. The complete procedure from the single $2-3 \mathrm{~mm} \times 1 \mathrm{~mm}$ trabeculectomy biopsy to the cryopreservation procedure (two $1.8 \mathrm{ml}$ vials) took approx. 25 days (Tables 2 and 4). Application of 10\% DMEM alone resulted in isolation failure: after a 26-day culture, there were only single fibroblasts and a few clusters of epithelial-like cells (Table 3, Fig. 2e). Medium replacement to 5\% FGF-EMEM at this point led to HTF recovery, but the isolation procedure (from biopsy to cryopreservation) was extended to approx. 45 days (Tables 3 and 4). It should be noted that ready-to-use specialist media enriched with FGFs and designed for optimal growth of fibroblasts would be also appropriate for HTF isolation. In our other studies, we used Quantum 333 medium (PAA Laboratories) supplemented with 5\% FBS (5\% Quantum 333) and we achieved comparable successful results. Similarly to $5 \%$ FGF-EMEM, the complete procedure from the single trabeculectomy biopsy to cryopreservation procedure took approx. 27 days (see Additional file 2).

According to the available literature, there are some protocols for primary Tenon's fibroblast isolation $[4,5,14]$. Most papers present effective isolation of Tenon's fibroblasts or trabecular meshwork cells using a complicated collagenase digestion method [1, 5] with basal culture media such as MEM [15], DMEM [1, 4, 14, 16] or RPMI-1640 [4, 17]. According to these protocols, successful HTF isolation requires long-term culture of the tissue explants: approx. 20-30 days to the first monolayer [14] unless whole eye tissue is used [1]. As trabeculectomy biopsies are very tiny (approx. $2 \mathrm{~mm}$ in length), most researchers describe isolation from relatively large tissue specimens obtained during other ophthalmologic surgeries, e.g. vitrectomy [14], or obtained from fibrotic scars formed after trabeculectomy $[17,18]$. There are only a few protocols in the available literature describing HTF isolation from tissue biopsies obtained during glaucoma filtering surgery $[15,16]$.

Since FBS is a complex mixture of a large number of biologically active molecules, such as growth factors, hormones, binding and transport proteins, attachment and spreading factors, amino acids, vitamins, trace elements, fatty acids, lipids, or protease-inhibitors, 


\section{HTF proliferation}

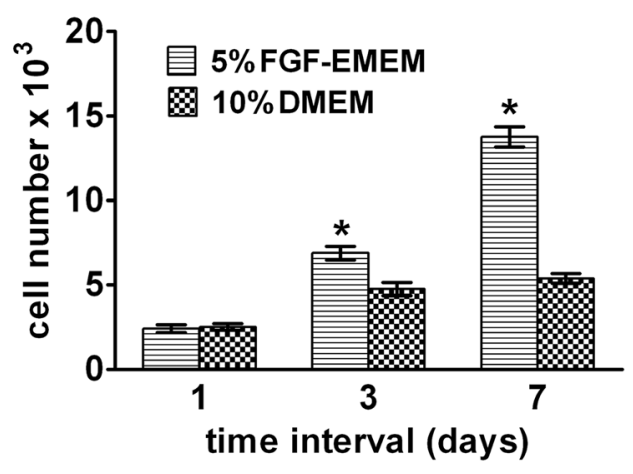

\begin{tabular}{ccc}
\hline & growth rate & doubling time $(h)$ \\
\hline 5\% FGF-EMEM & 0.0214 & 32.33 \\
$10 \%$ DMEM & 0.0151 & 45.92
\end{tabular}

Fig. 6 Proliferation of HTFs during parallel cultivation in 5\% FGF-EMEM and 10\% DMEM assessed using the WST-8 proliferation test. Results are expressed as means \pm SD. *Significantly more cells $\left(p=0.0012\right.$ on the $3^{\text {rd }}$ day, $p<0.0001$ on the $7^{\text {th }}$ day) compared to $10 \%$ DMEM according to the unpaired t-test (GraphPad Prism 5, Version 5.03 Software)

the $10 \%$ supplementation of the culture medium with FBS is commonly recommended for cultivation of the vast majority of cell lines and primary cultures [19]. However, in the case of isolation of specific cell types, a serum-free culture system consisting of basal medium supplemented with growth factors, vitamins and hormones is recommended. Because serum-free media do not have any attachment/spreading factors, a pre-coating of culture dishes with components of the ECM (e.g. collagen, fibronectin) is often required. Another approach includes the use of a low concentration of FBS in culture medium (low-serum medium) instead of pre-coating of culture vessels to provide adhesive proteins (fibronectin, vitronectin, collagen), which are essential for adhesion and survival of anchorage-dependent cells [19].

In this protocol, basal EMEM was supplemented with FGF, insulin and ascorbic acid to selectively promote fibroblast proliferation. Based on the available literature, FGF

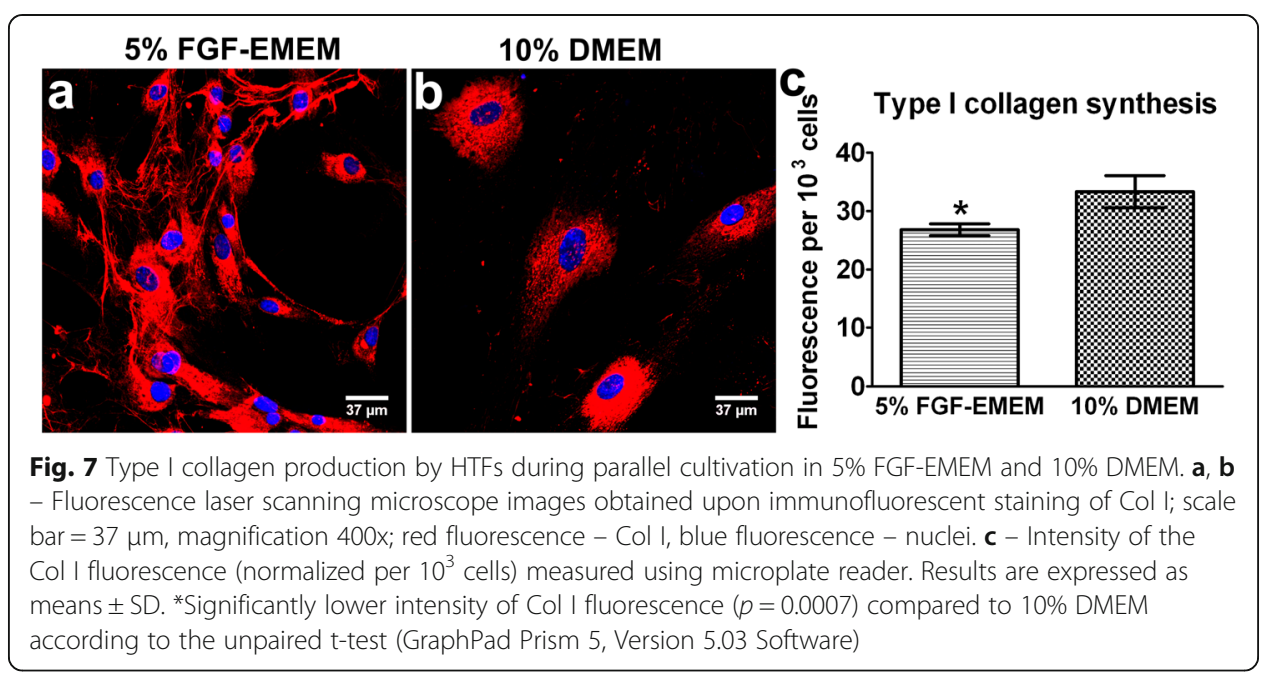


promotes fibroblast proliferation and maintains the normal biological function of these cells $[19,20]$, whereas ascorbic acid not only stimulates fibroblast proliferation [21], but also induces enhanced type I and III collagen synthesis [21, 22]. Insulin is also known to promote fibroblast proliferation [23], as its degradation products mimic the growthstimulatory activity of insulin-like growth factors and somatomedins [19]. FBS was added to EMEM at a low concentration of $5 \%$ only to provide essential adhesive proteins, spreading factors and trace elements. During the isolation procedure with DMEM, the FBS was the only source of growth factors, vitamins and hormones, so it was applied at a higher concentration (10\%). The proliferation test, which was performed for HTFs cultured in 5\% FGF-EMEM and 10\% DMEM, clearly proved that addition of FGF, ascorbic acid and insulin to the basal medium significantly enhances fibroblast proliferation (Fig. 6).

Parallel cultivation of isolated HTFs in 5\% FGF-EMEM and 10\% DMEM revealed great differences in fibroblast behaviour. HTFs maintained in 5\% FGF-EMEM were small spindle- or stellate-shaped fibroblasts with centrally placed oval nuclei, which is characteristic of active, mitotic fibroblasts $[24,25]$. The cells in 5\% FGF-EMEM were either fibroblasts in a late interphase just before mitosis or very small daughter cells after division, which had not reached their critical size to enter the subsequent mitosis (Fig. 5a) [26, 27]. The cells cultured in 10\% DMEM were mostly large stellate-shaped cells. According to the available literature, large spindle- and stellate-shaped cells are post-mitotic fibroblasts [25] that do not have the DNA synthesis ability and thus do not enter mitosis [28]. However, post-mitotic cells possess an increased ability to produce other macromolecules, e.g. proteins [27, 28]. In this study, it was demonstrated that cells maintained in $10 \%$ DMEM stopped dividing on the $3^{\text {rd }}$ day of the experiment (Fig. 6) and consumed all of the available energy for protein synthesis and growth. It was also proved that HTFs cultured in 10\% DMEM were almost 4-fold larger than cells cultivated in 5\% FGF-EMEM (Fig. 5c) and produced relatively high amounts of Col I protein (Fig. 7c), which was not released to the extracellular space but was accumulated inside the cells (Fig. 7b). Thus, it may be inferred that large stellate-shaped cells cultured in 10\% DMEM were mostly post-mitotic fibroblasts.

According to the available literature, ascorbic acid enhances type I and III collagen production by fibroblasts [21, 22]. Interestingly, in this study it was demonstrated that cells cultured in 5\% FGF-EMEM produced slightly lower amounts of Col I compared to HTFs maintained in 10\% DMEM (Fig. 7c). Nevertheless, unlike the cells cultivated in $10 \%$ DMEM, they revealed the ability to form large collagen fibrils, which were deposited in great amounts in the ECM (Fig. 7a and b). Thus, it may be assumed that ascorbic acid does not enhance Col I synthesis but rather induces ECM formation by promoting the excretion of collagen molecules into the extracellular space and their assembly into fibrils.

\section{Conclusions}

The HTF isolation protocol presented here is a simple, fast method to obtain great number of cells $\left(1.3 \times 10^{6}\right.$ vimentin-positive fibroblasts) from a single $2-3 \mathrm{~mm} \times 1 \mathrm{~mm}$ trabeculectomy biopsy within approx. 25 days. Our protocol may allow for easy setup of cell banks under laboratory conditions and for novel ophthalmologic drug testing in vitro. It was also demonstrated that 5\% FGF-EMEM is a better choice than $10 \%$ 
DMEM for fast propagation of HTFs before the preparation of the experiments. However, in the case of the studies aiming to assess the effect of a tested agent on proliferation rate or type I collagen production ability, 5\% FGF-EMEM should be used only for isolation of HTFs, and then 10\% DMEM should be applied for experimental setup, as 5\% FGF-EMEM significantly affects cell divisions and the ECM-forming ability of fibroblasts.

\section{Additional files}

Additional file 1: Viability of the cells upon thawing. Report generated using a Countess automated cell counter upon thawing of HTFs isolated from sample 3. The vial contained $1.8 \mathrm{ml}$ of cell suspension. (TIF $5742 \mathrm{~kb}$ )

Additional file 2: Isolation performed with ready-to-use FGF-enriched medium. Example of another FGF-enriched medium (specialist Quantum 333) giving similar successful results. A - Nomarski contrast image of HTF monolayer 17 days after passage 1 when 5\% Quantum 333 was used; scale bar $=150 \mu \mathrm{m}$, magnification 100x. B - Fluorescence laser scanning microscope image of HTF culture $48 \mathrm{~h}$ after passage 2 when 5\% Quantum 333 was used; white arrows indicate single actin-positive/vimentin-negative cells; scale bar $=75 \mu \mathrm{m}$, magnification 200x; green fluorescence - vimentin filaments, red fluorescence - F-actin filaments, blue fluorescence - nuclei. (TIF $8732 \mathrm{~kb}$ )

\section{Abbreviations}

BSA: Bovine serum albumin; Col I: Type I collagen; DMEM: Dulbecco's modified Eagle's medium; ECM: Extracellular matrix; EMEM: Eagle's minimum essential medium; FBS: Foetal bovine serum; FGF: Fibroblast growth factor; HTF: Human Tenon's fibroblast; IOP: Intraocular pressure; PBS: Phosphate buffered saline

\section{Acknowledgments}

The authors would like to thank Michal Wojcik from the Department of Biochemistry and Biotechnology, Medical University of Lublin, Poland, for his help with the fluorescence laser scanning microscope analyses.

\section{Funding}

Financial assistance was provided by the Ministry of Science and Higher Education in Poland within DS179 project of the Medical University of Lublin. This research was done using equipment purchased within agreement No. POPW.01.03.00-06-010/09-00 Operational Programme Development of Eastern Poland 2007-2013, Priority Axis I, Modern Economy, Operations 1.3. Innovations Promotion.

\section{Availability of data and materials}

All data generated or analyzed during this study are included in this published article and its supplementary files.

\section{Authors' contributions}

AP performed HTF isolation, established the protocol, performed all cell culture experiments, and wrote the manuscript. TZ performed glaucoma surgery and collected tissue biopsies. GG is a senior professor and assisted in the preparation of the manuscript draft. All authors read and approved the final manuscript.

\section{Competing interests}

The authors declare that they have no competing interests.

\section{Ethics approval and consent to participate}

The protocol was conducted in compliance with the tenets of the Declaration of Helsinki for experiments involving human tissues and under ethical approval issued by the Bioethics Committee of Medical University of Lublin (0254/ 138/2016). Written informed consent was obtained from the patients before glaucoma filtering surgery.

\section{Author details}

${ }^{1}$ Department of Biochemistry and Biotechnology, Medical University of Lublin, Chodzki 1 Street, 20-093 Lublin, Poland. ${ }^{2}$ Department of Ophthalmology, Medical University of Lublin, Chmielna 1 Street, 20-079 Lublin, Poland.

Received: 26 October 2016 Accepted: 14 February 2017

Published online: 09 March 2017

\section{References}

1. Stamer DW, Roberts BC, Epstein DL, Allingham RR. Isolation of primary open-angle glaucomatous trabecular meshwork cells from whole eye tissue. Curr Eye Res. 2000;20(5):347-50

2. Williams DE, Nguyen KD, Shapourifar-Tehrani S, Kitada S, Lee DA. Effects of timolol, betaxolol, and levobunolol on human tenon's fibroblasts in tissue culture. Invest Ophthalmol Vis Sci. 1992;33(7):2233-41.

3. Jurkowska-Dudzinska J, Kosior-Jarecka E, Zarnowski T. Comparison of the use of 5-fluorouracil and bevacizumab in primary trabeculectomy: results at 1 year. Clin Experiment Ophthalmol. 2012;40:e135-42. 
4. Md Noh SM, Sheikh Abdul Kadir SH, Bannur ZM, Froemming GA, Abdul Hamid Hasani N, Mohd Nawawi H, Crowston JG, Vasudevan S. Effects of ranibizumab on the extracellular matrix production by human Tenon's fibroblast. Exp Eye Res. 2014;127:236-42.

5. Nakamura-Shibasaki M, Ko JA, Takenaka J, Chikama T, Sonoda KH, Kiuchi Y. Matrix metalloproteinase and cytokine expression in Tenon fibroblasts during scar formation after glaucoma filtration or implant surgery in rats. Cell Biochem Funct. 2013;31(6):482-8.

6. Lama PJ, Fechtner RD. Antifibrotics and wound healing in glaucoma surgery. Surv Ophthalmol. 2003;48:314-46.

7. Wong T, Khaw P, Aung T, Foster PJ, Htoon HM, Oen FT, Gazzard G, Husain R, Devereux JG, Minassian D, Tan SB, Chew PT, Seah SK. The Singapore 5-fluorouracil trabeculectomy study: effects on intraocular pressure control and disease progression at 3 years. Ophthalmology. 2009;116:175-84.

8. WuDunn $\mathrm{O}$, Cantor LB, Palanca-Capistrano AM. A prospective randomized trial comparing intraoperative 5 -flourouracil versus mitomycin C in primary trabeculectomy. Am J Ophthalmol. 2002;134:521-8.

9. Jonas JB, Spandau UH, Schlichtenbrede F. Intravitreal bevacizumab for filtering surgery. Ophthalmic Res. 2007;39:121-2

10. Memarzadeh F, Varma R, Lin L, Parikh JG, Dustin L, Alcaraz A, Eliott D. Postoperative use of bevacizumab as an antifibrotic agent in glaucomafiltration surgery in the rabbit. Invest Ophthalmol Vis Sci. 2009;50:3233-7.

11. Zarnowski T, Tulidowicz-Bielak M. Topical bevacizumab is efficacious in the early bleb failure after trabeculectomy. Acta Ophthalmol. 2009;89(7):e605-6

12. Klos-Rola J, Tulidowicz-Bielak M, Zarnowski T. Effects of topical bevacizumab application on early bleb failure after trabeculectomy: observational case series. Clin Ophthalmol. 2013;7:1929-35.

13. Przekora A, Ginalska G. Enhanced differentiation of osteoblastic cells on novel chitosan/ $\beta$-1,3-glucan/bioceramic scaffolds for bone tissue regeneration. Biomed Mater. 2015. doi:10.1088/1748-6041/10/1/015009.

14. De Falco E, Scafetta G, Napoletano C, Puca R, Vingolo EM, Ragona G, lorio O, Frati G. A standardized laboratory and surgical method for in vitro culture isolation and expansion of primary human Tenon's fibroblasts. Cell Tissue Bank. 2013;14(2):277-87.

15. Gross RL. Collagen type I and III synthesis by Tenon's capsule fibroblasts in culture: individual patients characteristics and response to mitomycin-C, 5-fluorouracil, and ascorbic acid. Tr Am Ophth Soc. 1999;97:513-43.

16. Khaw PT, Ward S, Porter A, Grierson I, Hitchings RA, Rice NS. The long-term effects of 5-fluorourocil and sodium butyrate on human Tenon's fibroblasts. Invest Ophthalmol Vis Sci. 1992;33(6):2043-52.

17. Leng F, Liu P, Li H, Zhang J. Long-term topical antiglaucoma medications cause enhanced Tenon's capsule fibroblast proliferation and abnormal TGF- $\beta$ and MMP expressions: potential effects on glaucoma filtering surgery. Curr Eye Res. 2011;36(4):301-9.

18. Fuchshofer R, Kottler UB, Ohlmann AV, Schlötzer-Schrehardt U, Jünemann A, Kruse FE, Ohlmann A. SPARC is expressed in scars of the Tenon's capsule and mediates scarring properties of human Tenon's fibroblasts in vitro. Mol Vis. 2011;17:177-85.

19. Gstraunthaler G. Alternatives to the use of fetal bovine serum: serum-free cell culture. ALTEX. 2003;20(4):275-81.

20. Yun Y-R, Won JE, Jeon E, Lee S, Kang W, Jo H, Jang J-H, Shin US, Kim H-W. Fibroblast growth factors: biology, function, and application for tissue regeneration. J Tissue Eng. 2010. doi:10.4061/2010/218142.

21. Phillips $\mathrm{CL}$, Combs SB, Pinnell SR. Effects of ascorbic acid on proliferation and collagen synthesis in relation to the donor age of human dermal fibroblasts. J Invest Dermatol. 1994;103(2):228-32.

22. Tajima S, Pinnell SR. Ascorbic acid preferentially enhances type I and III collagen gene transcription in human skin fibroblasts. J Dermatol Sci. 1996;11(3):250-3.

23. Monaco S, Illario M, Rusciano MR, Gragnaniello G, Di Spigna G, Leggiero E, Pastore L, Fenzi G, Rossi G, Vitale M. Insulin stimulates fibroblast proliferation through calcium-calmodulin-dependent kinase II. Cell Cycle. 2009:8(13):2024-30

24. Ravikanth M, Soujanya P, Manjunath K, Saraswathi T, Ramachandran C. Heterogenecity of fibroblasts. J Oral Maxillofac Pathol. 2011;15(2):247-50

25. Mathew DG, Skariah KS, Ranganathan K. Proliferative and morphologic characterization of buccal mucosal fibroblasts in areca nut chewers: a cell culture study. Indian J Dent Res. 2011. doi:10.4103/0970-9290.94693.

26. Lloyd AC. The regulation of cell size. Cell. 2013;154(6):1194-205.

27. Jorgensen P, Tyers M. How cells coordinate growth and division. Curr Biol. 2004;14(23):R1014-27.

28. Marguerat S, Bähler J. Coordinating genome expression with cell size. Trends Genet. 2012;28(11):560-5.

\section{Submit your next manuscript to BioMed Central and we will help you at every step:}

- We accept pre-submission inquiries

- Our selector tool helps you to find the most relevant journal

- We provide round the clock customer support

- Convenient online submission

- Thorough peer review

- Inclusion in PubMed and all major indexing services

- Maximum visibility for your research

Submit your manuscript at www.biomedcentral.com/submit 